\title{
Trophic interactions and carbon flow between picoplankton and protozoa in pelagic enclosures manipulated with nutrients and a top predator
}

\author{
Pirjo Kuuppo-Leinikki ${ }^{1}$, Riitta Autio ${ }^{1}$, Seija Hällfors ${ }^{1}$, Harri Kuosa ${ }^{2}$, \\ Jorma Kuparinen ${ }^{2}$, Riitta Pajuniemi ${ }^{1}$ \\ ${ }^{1}$ Tvärminne Zoological Station, SF-10900 Hanko, Finland \\ ${ }^{2}$ Finnish Institute of Marine Research, PO Box 33, SF-00931 Helsinki, Finland
}

\begin{abstract}
Experimental enclosures were used to follow responses of the planktonic microbial food web to varying short-term $(5 \mathrm{~d})$ perturbations induced by adding inorganic nutrients $(\mathrm{N}$ and $\mathrm{P}$ ) and a top predator (fish) during a $21 \mathrm{~d}$ period in late summer, on the coastal area of the Baltic Sea. Biomass, production, growth and grazing of pico- and nanoplankton assemblages were estimated, and a carbon budget for the microbial loop during the experiment was constructed. The microbial food web was a highly dynamic system. Varying perturbations due to nutrient loading and the top predator provoked eutrophication in the enclosures, but they affected the microbial loop only slightly. The amplitudes of oscillation in abundance of coupled communities were amplified, but the frequencies of oscillations in the microbial loop were not affected by the perturbations. Changes in the route of carbon flow through the microbial food web occurred in relatively short time scales. These changes seemed to be dependent on the phasing of the coupled oscillations between the communities, and the structure within the different communities. Ciliates were only loosely connected to the microbial loop: although ciliates and heterotrophic nanoflagellates (HNF) showed predator-prey-like coupled oscillations, the ciliates gained most of their carbon from other sources, and most of the HNF carbon loss was due to factors other than ciliates. HNF were the most important consumers of picoplankton during the HNF maximum, but they were also dependent on other sources of nutrition.
\end{abstract}

KEY WORDS: Microbial food web - Carbon budget - Experimental enclosures

\section{INTRODUCTION}

The microbial food web is presently recognised as one of the basic elements of the pelagic ecosystem in both marine and freshwater environments (Pomeroy 1974, Azam et al. 1983). Carbon is transformed into particulate organic form either by heterotrophic bacteria, by autotrophic picoplanktonic cyanobacteria, or by pico-sized eukaryotic algae, and channelled through the microbial food web towards the grazing food web.

Grazing by heterotrophic nanoflagellates is considered the principal loss process for picoplankton in most aquatic habitats (Fenchel 1982b, Rassoulzadegan \& Sheldon 1986, Wikner \& Hagström 1988, Bloem et al.
1989, Weisse 1990, Caron et al. 1991, Kuosa 1991b, Sanders et al. 1992). In addition, grazing by mixotrophic algae (Bird \& Kalff 1987, Sanders \& Porter 1988, Søndergaard et al. 1988, Bennett et al. 1990), heterotrophic ciliates (Gast 1985, Rivier et al. 1985 , Albright et al. 1987, Sherr \& Sherr 1987, Sherr et al. 1989), and larger zooplankton — in fresh waters especially cladocerans (Geertz-Hansen et al. 1987, Christoffersen et al. 1990, Wylie \& Currie 1991, Jeppesen et al. 1992, Vagué \& Pace 1992) - has also been regarded as potential loss process for picoplankton.

The spatio-temporal dynamic structure of the planktonic food web dictates the importance of different organisms as grazers of picoplankton, and thus also the fate of primary and secondary picoplankton produc- 
tion (Sanders et al. 1989, Bennett et al. 1990, Christoffersen et al. 1990, Pace et al. 1990, Vagué \& Pace 1992). The efficiency with which matter is transferred to higher trophic levels depends on the number of predator-prey interactions within the food chain and the assimilation efficiency of organisms (Ducklow et al. 1986, Pomeroy \& Wiebe 1988). In a long food chain involving many predator-prey steps, for example within the nanoflagellate assemblage (Wikner \& Hagström 1988), this transfer is inefficient as a great deal of the carbon is respired.

Bacteria and heterotrophic nanoflagellates, as well as nanoflagellates and ciliates, exhibit predator-prey oscillations both in natural environments and under experimental conditions (Andersen \& Sørensen 1986, Rassoulzadegan \& Sheldon 1986, Lucas et al. 1987 , Bjørnsen et al. 1988). This implies their close association within the food web and a regulation of the organisms that fluctuates between bottom-up (nutrient or food supply) and top-down (predator effect) (Wright 1988) control.

In order to examine the dynamics and the controlling factors of pelagic ecosystems, several studies of the pelagial community have been conducted using experimental enclosures. These experiments included manipulation of the community by excluding predators, by introducing predators (top-down control), or by adding inorganic substrates or bacterial substrates to the system (bottom-up control) (e.g. Bjornsen et al. 1988, Christoffersen et al. 1990, Riemann et al. 1990, Lignell et al. 1992, Kivi et al. 1993).

In the present study, on the coast of the Baltic Sea, we used enclosures to follow the development and fate of phytoplankton blooms as well as the response of the planktonic food web to varying short-term (5 d) perturbations. These perturbations were in the form of inorganic nutrient additions ( $N$ and $P$ ) and the inclusion of a top predator (fish) during a $21 \mathrm{~d}$ period in late summer. Kivi et al. (1993) have shown that such short-term manipulations are of sufficient duration for the planktonic community to respond to the nutrient and predator additions. The manipulations during the experiment were chosen in order to affect the structure and functioning of the pelagic community both from 'above' (to achieve cascading effects of a top predator) and 'below' (to achieve cascading effects of increased nutrient availability). Consequently, several interconnected analyses of different trophic compartments of the food web were pursued within the experiment. This paper concentrates on the dynamics of the microbial food web in the enclosures. All estimates of biomass, bacterial production (including the thymidine incorporation conversion factor), growth rates of cyanobacteria and nanoflagellates, and grazing on both heterotrophic and autotrophic picoplankton were based on measurements from the enclosures during the experiment. These measurements were used to outline carbon flow through the microbial community in the enclosures.

\section{MATERIAL AND METHODS}

Study area. The study site was located in the coastal area off the Tvärminne Zoological Station at the entrance to the Gulf of Finland in the Baltic Sea. Depth at the sampling site is ca $15 \mathrm{~m}$ and salinity 5 to $6 \%$. Occasional upwellings of cold nutrient-rich water, and outflows of less saline water from the Pojo Bay, are characteristic for the area. A detailed description of the area is presented in Niemi (1975). At the beginning of the experiment, salinity of the water was $6 \%$ and inorganic nitrogen and phosphorus were depleted from the water column. Freshwater species were found in both the phytoplankton and zooplankton communities (e.g. Cyclotella spp., Diatomophyceae; Closterium acutus, Chlorophyceae; Coelastrum spp., Chlorophyceae; Daphnia pulex, Cladocera).

Experimental design. The experiment was carried out between 23 July and 12 August 1988. Five plastic enclosures (vol. ca $30 \mathrm{~m}^{3}$, diam. $2.15 \mathrm{~m}$, depth $8 \mathrm{~m}$ ), which were closed at the bottom, were filled with brackish water (salinity $6 \%$ ) by raising them from a depth of $15 \mathrm{~m}$ to the floating collar where they were mounted. The enclosures were manipulated through additions of inorganic nitrogen and phosphate, and first-year stickleback Gasterosteus aculeatus fry. The experimental design is presented in Table 1. Daily additions of inorganic nutrients $\left(\mathrm{PO}_{4}-\mathrm{P}: 4 \mathrm{mg} \mathrm{m}^{-3} \mathrm{~d}^{-1}\right.$ $\mathrm{NH}_{4}-\mathrm{N}: 16 \mathrm{mg} \mathrm{m}^{-3} \mathrm{~d}^{-1}$ ) were distributed evenly to the water column after sampling, beginning on Day 1 , using a plastic tube. The stickleback fry (90 ind. enclosure ${ }^{-1}$ ) were added to Enclosures 3 and 4 during Day 0 (the first experimental day). After sampling on Day 10 , the fish were removed from these units by drawing a round, $1 \mathrm{~mm}$ mesh net twice through the mesocosms,

Table 1. Experimental design. nm: no manipulation; $\mathrm{P}+\mathrm{N}$ $4 \mathrm{mg} \mathrm{PO}_{4}-\mathrm{P}+16 \mathrm{mg} \mathrm{NH}_{4}-\mathrm{N} \mathrm{m}^{-3} \mathrm{~d}^{-1} ; \mathrm{F}: 90$ stickleback fry enclosure $^{-1}$

\begin{tabular}{|ccccc|}
\hline & \multicolumn{4}{c|}{ Period } \\
& I & II & III & IV \\
Days: & $0-4$ & $5-9$ & $10-14$ & $15-20$ \\
\hline Enclosure 1 & $\mathrm{nm}$ & $\mathrm{P}+\mathrm{N}$ & $\mathrm{F}$ & $\mathrm{P}+\mathrm{N}+\mathrm{F}$ \\
Enclosure 2 & $\mathrm{P}+\mathrm{N}$ & $\mathrm{nm}$ & $\mathrm{P}+\mathrm{N}+\mathrm{F}$ & $\mathrm{F}$ \\
Enclosure 3 & $\mathrm{F}$ & $\mathrm{P}+\mathrm{N}+\mathrm{F}$ & $\mathrm{nm}$ & $\mathrm{P}+\mathrm{N}$ \\
Enclosure 4 & $\mathrm{P}+\mathrm{N}+\mathrm{F}$ & $\mathrm{F}$ & $\mathrm{P}+\mathrm{N}$ & $\mathrm{nm}$ \\
Control & $\mathrm{nm}$ & $\mathrm{nm}$ & $\mathrm{nm}$ & $\mathrm{nm}$ \\
& & & & \\
\hline
\end{tabular}


and at the same time new sticklebacks were introduced into Enclosures 1 and 2.

As an additional, non-controllable variable, water temperature was found to fluctuate between 11.2 and $21.5^{\circ} \mathrm{C}$ during the experiment (Fig. 1). A drastic temperature drop occurred between Days 6 and 7 as the consequence of an upwelling.

Sampling. Water samples were taken in the morning between 7:00 and 8:00 h with a Ruttner-type sampler. Subsamples for cell counts and bacterial production measurements were taken from an integrated $0,1,2,3$, 4 and $5 \mathrm{~m}$ sample. Primary production, bacterial production, and the numbers of bacteria and picoplanktonic cyanobacteria were measured daily. Cell numbers of picoplanktonic photosynthetic eukaryotes, nanoflagellates and ciliates were measured from Day 0 onwards at 2 to $3 \mathrm{~d}$ intervals. To study the vertical distribution of the organisms, and of bacterial production, samples from $0,1,2,3,4$ and $5 \mathrm{~m}$ depth were taken on Days 0, 5, 10, 15 and 20 from Enclosure 1.

Chlorophyll a (chl a), bacterial production and biomass were also measured outside the enclosures so as to compare the control enclosure (5) to the succession in the sea.

Chlorophyll $a$ and biomass determinations. Duplicate $50 \mathrm{ml}$ water samples were filtered onto a Whatman GF/F filter for chl a measurements. Chl a was then extracted with $94 \%$ ethanol for $24 \mathrm{~h}$ in darkness, at room temperature, and measured with a SequoiaTurner 450 fluorometer (calibrated with pure chl $a_{i}$ Sigma Chem. Co., St. Louis, MO, USA).

All organisms, except ciliates, were counted with a Leitz Dialux microscope equipped with epifluorescence light (50 W HBO mercury lamp) and with a $100 \times$ oil immersion objective.

Samples for estimating biomass of bacteria (BACT) were fixed with unbuffered formalin (final conc. $2 \%$ ). A $2 \mathrm{ml}$ subsample was filtered onto black $0.2 \mu \mathrm{m}$ Nuclepore filters and stained with acridine orange (Hobbie et al. 1977). A total of several hundred bacterial cells was counted from 20 fields under blue excitation (filter block I 2/3). Bacterial cell numbers were converted to carbon using a coefficient of $0.041 \mathrm{\mu m}^{3}$ cell $^{-1}$ for volume (Kuuppo-Leinikki 1990) and 0.35 pg C $\mu \mathrm{m}^{-3}$ for carbon (Bjornsen 1986)

Subsamples for counting both photosynthetic (PNF) and heterotrophic (HNF) nanoflagellates as well as picoplanktonic cyanobacteria (PCYA) and eukaryotes (PEUC) were fixed with unbuffered glutaraldehyde (final conc. $1 \%$ ). Slides for microscopy were prepared by filtering a $5 \mathrm{ml}$ subsample onto a black $0.2 \mu \mathrm{m}$ Nuclepore filter (vacuum $<3 \mathrm{kPa}$ ). The nanoflagellates were stained with proflavine (Haas 1982, Kuosa 1988a), and counted under blue excitation (filter block I 2/3). As a rule, nanoflagellates were counted from

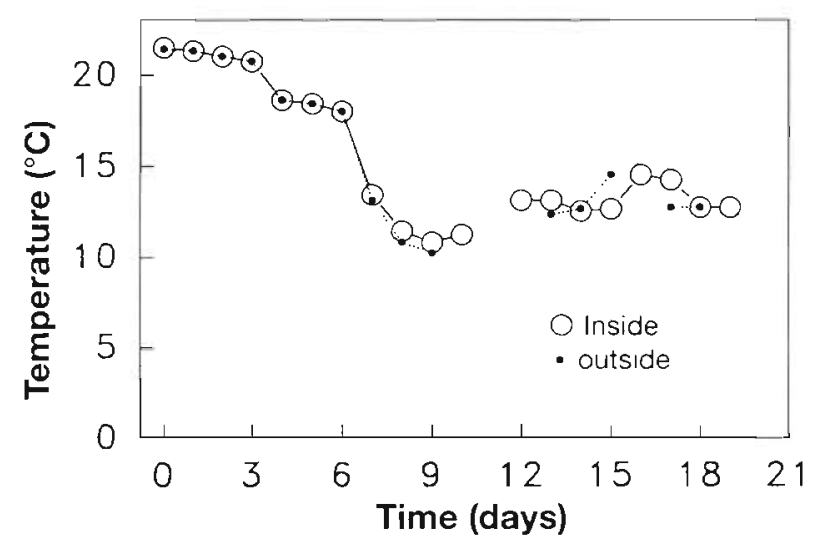

Fig. 1. Water temperature inside and outside the mesocosms in the Tvärminne area of the Baltic Sea between 23 July and 12 August 1988

100 (in some cases 50) fields, which yielded from 40 to 260 HNF cells and from 50 to 640 PNF cells. The PNF were distinguished from HNF by the red autofluorescence of chl a. The nanoflagellates were counted from duplicate filters. The lower value of the duplicates was on average $85 \%$ of the higher value (CV $12.5 \%$ ). HNF were converted to carbon using a conversion factor of $25.9,17.0,23.6$ and $39.2 \mu^{3}$ cell $^{-1}$ for volume, during Periods I to IV respectively (Kuuppo-Leinikki 1990), and a factor of $0.22 \mathrm{pg} \mathrm{C} \mu \mathrm{m}^{-3}$ for carbon (Børsheim \& Bratbak 1987). The volume estimate for PNF was obtained from the average volume of the 6 most common nanoflagellate genera $\left(6.64\right.$ to $56.46 \mu^{3}$, estimated from samples preserved with Lugol's iodine solution). The carbon conversion factor used was $11 \%$ of the PNF volume, in accordance with Edler et al. (1979).

PEUC where identified by their red autofluorescence under blue light. PCYA were counted from the same fields and distinguished by the orange autofluorescence of phycoerythrin under green excitation (filter block M2). At least 200 cells were counted from every sample. The volume and carbon conversion factors used for PCYA were, respectively, $0.38 \mu^{3} \mathrm{cell}^{-1}$ (Kuosa 1988b) and $0.22 \mathrm{pg} \mathrm{C} \mathrm{mm}^{-3}$ (Li 1986), and for

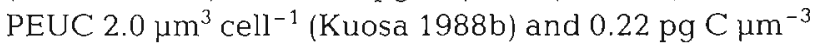
(Li 1986)

Ciliates were preserved with Lugol's iodine solution and counted using the Utermöhl technique using an inverted microscope. Their carbon content was calculated as $11 \%$ of their mean wet weight, according to the standards of the Baltic Marine Biologists (Edler 1979).

Primary and bacterial production. Primary production (apparent net) was measured from ${ }^{14} \mathrm{C}$ uptake (Steemann-Nielsen 1952) according to the procedure described in Lignell \& Lindquist (1992). 
Bacterial cell production (BPROD) was estimated from the incorporation of ${ }^{3} \mathrm{H}$-thymidine into cold TCA precipitate (Fuhrman \& Azam 1980). Duplicate subsamples of $10 \mathrm{ml}$ and a formalin-killed adsorption control (final conc. $0.5 \%$ formalin) were incubated in situ with $10 \mathrm{nM}$ of [methyl ${ }^{3} \mathrm{H}$ ]-thymidine $\left(40\right.$ to $42 \mathrm{Ci} \mathrm{mmol}^{-1}$; Radiochemical Centre, Amersham, Buckinghamshire, UK) for $30 \mathrm{~min}$. The incubation was terminated by adding formalin (final conc. $0.5 \%$ ). The samples were extracted in TCA under ice-cold conditions, and the cold-TCAinsoluble material was collected onto cellulose acetate filters (Sartorius, pore size $0.2 \mu \mathrm{m}$ ). Radioactivity on the filters was assayed with an LKB-Wallac 1219 RackBeta liquid scintillation counter, using PCS (Amersham) as the scintillation cocktail.

A factor for converting thymidine incorporation to bacterial cell production $\left(2.64 \times 10^{18}\right.$ cells $\left.\mathrm{mol}^{-1}\right)$ was determined during the experiment in Enclosure 1 (Autio 1992).

Non-parametric analysis (Spearman rank correlation) was used to study the correlation of chl $a, P N F$, PEUC and PCYA in the enclosures. Only the sampling dates when all variables were measured were included in the analysis.

Carbon budget. A carbon budget was established for Enclosure 1 as follows:

Production: Bacterial production was measured from the thymidine incorporation rate as described above. The production of HNF and PCYA in the enclosures was estimated from their growth constants $(\mu$; based on $\log _{2}$ ) in $<1 \mu \mathrm{m}$ and $<5 \mu \mathrm{m}$ filtered batch cultures, at in situ temperatures during the experiment (a detailed description of the fractionation technique is given in Kuuppo-Leinikki 1990 and Kuosa 1991a):

$$
\text { Cell production }\left(\mathrm{ml}^{-1} \mathrm{~h}^{-1}\right)=N_{j} \mu / t
$$

where $N_{1}=$ microscopically observed cell number at time $T_{i}$; and $t=$ time between successive samplings $(\mathrm{h})$. The growth constants $(\mu)$ varied between 0.03 and $0.60 \mathrm{~d}^{-1}$ for PCYA and from 0.04 to $1.44 \mathrm{~d}^{-1}$ for HNF (Kuosa 1991a).

Losses: Total losses of HNF, PCYA and BACT were calculated from the differences between observed and estimated (based on cell production) increases in cell numbers between successive samplings. Protozoan grazing on BACT, PCYA and HNF was measured in Enclosure 1 using the size fractionation technique (Kuuppo-Leinikki 1990, Kuosa 1991b). The clearance rates used in the carbon budget are presented in Table 2.

An estimate of ciliate (CIL) grazing on BACT in the carbon budget was calculated as:

(Grazing in the $<100 \mu \mathrm{m}$ fraction)

- (Grazing in the $<5 \mu \mathrm{m}$ fraction)
Table 2. Protozoan clearance rates of BACT, PCYA and HNF used in the carbon flow budget

\begin{tabular}{|c|c|c|c|c|}
\hline \multirow[t]{2}{*}{ Clearance rate of: } & \multicolumn{4}{|c|}{ Period } \\
\hline & I & II & III & IV \\
\hline \multicolumn{5}{|c|}{$\operatorname{BACT}^{d}\left(\mathrm{nl} \mathrm{HNF} F^{-1} h^{-1}\right)$} \\
\hline$<5 \mu \mathrm{m}$ & 1.9 & 3.9 & 0.6 & 5.3 \\
\hline$<100 \mu \mathrm{m}$ & 2.5 & 4.2 & 1.5 & 4.0 \\
\hline \multicolumn{5}{|c|}{$\mathrm{PCYA}^{b}\left(\mathrm{nl} \mathrm{HNF}^{-1} \mathrm{~h}^{-1}\right)$} \\
\hline$<5 \mu \mathrm{m}$ & 4.3 & 7.2 & 1.3 & 0.4 \\
\hline \multicolumn{5}{|c|}{$\mathrm{BACT}^{\mathrm{a}}\left(\mathrm{nl} \mathrm{CIL} \mathrm{L}^{-1} \mathrm{~h}^{-1}\right)$} \\
\hline$<100 \mu \mathrm{m}$ & 500 & 220 & 0 & 0 \\
\hline \multicolumn{5}{|c|}{${ }^{a}$ Kuuppo-Leinikki (1990); ${ }^{b}$ Kuosa (1991) } \\
\hline
\end{tabular}

The CIL grazing estimate also includes the potential impact of heterotrophic dinoflagellates. As cell numbers and size distribution of HNF were not significantly different between the $<5 \mu \mathrm{m}$ and $<100 \mu \mathrm{m}$ size fractions during Periods I and III in the grazing experiments (Kuuppo-Leinikki 1990), grazing rates in the $<5 \mu \mathrm{m}$ size fraction were considered to represent HNF grazing and the difference between the 2 fractions was considered to represent CIL grazing. The carbon production and loss rates were integrated over each $5 \mathrm{~d}$ manipulation period.

\section{RESULTS}

\section{Vertical distribution of the parameters}

PCYA, HNF and BPROD were evenly distributed throughout the water column in the enclosures (Fig. 2). The variations ( $\mathrm{CV}, \%$ ) of cell counts within the vertical profiles were on average 1.9,2.7,6.3, 10.3 and 18.5 for PCYA, BPROD, HNF, BACT and PNF, respectively. There were no distinct peaks in the distribution of the organisms, and we used the integrated sample as representative of the enclosures in the experiment.

\section{Chl $a$ and PNF}

Phytoplankton biomass (chl a) increased due to the addition of inorganic nutrients (Fig. 3). The sequence of manipulations caused different chl a successions in the enclosures. In Enclosures 2 and 4, where nutrients were added at the beginning of the experiment, the initial increase in phytoplankton biomass was immediate. The chl a peak did not occur until Period III in Enclosure 2, while in Enclosure 4, with the stickleback (Table 1), the chl a maximum already appeared after Period I. In Enclosures 2 and $4 \mathrm{chl}$ a concentrations 
Day 0

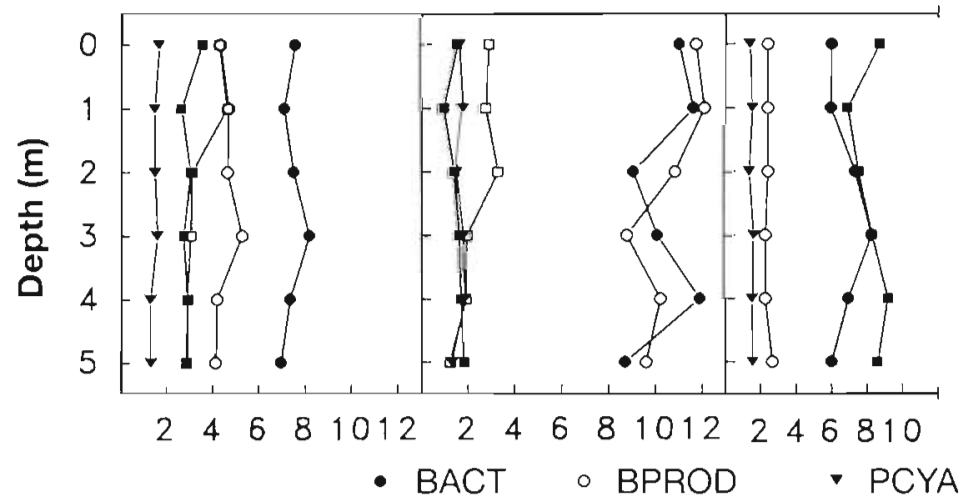

Day 15

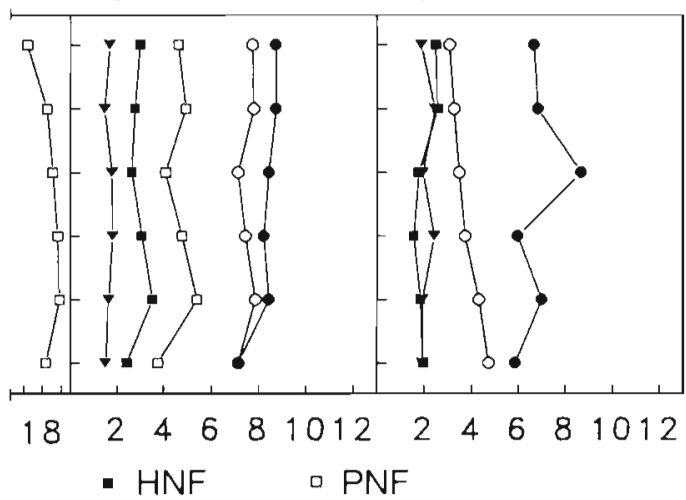

Fig. 2. Vertical distribution of bacterial numbers (BACT, cells $\times 10^{6} \mathrm{ml}^{-1}$ ), bacterial production (BPROD, cells $\times 10^{4} \mathrm{ml}{ }^{-1}$ ), picoplanktonic cyanobacteria (PCYA, cells $\times 10^{5} \mathrm{ml}^{-1}$ ), heterotrophic nanoflagellates ( $\mathrm{HNF}$, cells $\times 10^{3} \mathrm{ml}^{-1}$ ), and photosynthetic nanoflagellates (PNF, cells $\times 10^{3} \mathrm{ml}^{-1}$ ) in Enclosure 1

remained high during the remainder of the experiment (Fig. 3). Enclosures 1 and 3, which did not receive nutrient additions during Period I (Table 1), showed a biomass increase on Day 7 followed by a chlorophyll peak on Day 12. A new increase in chl a was obtained after the renewed addition of nutrients (Fig. 3, Table 1). In the control unit (Enclosure 5) and outside the enclosures (Fig. 3), a similar chl a succession was

ENCLOSURE 1 ENCLOSURE 2 ENCLOSURE 3 ENCLOSURE 4 CONTROL
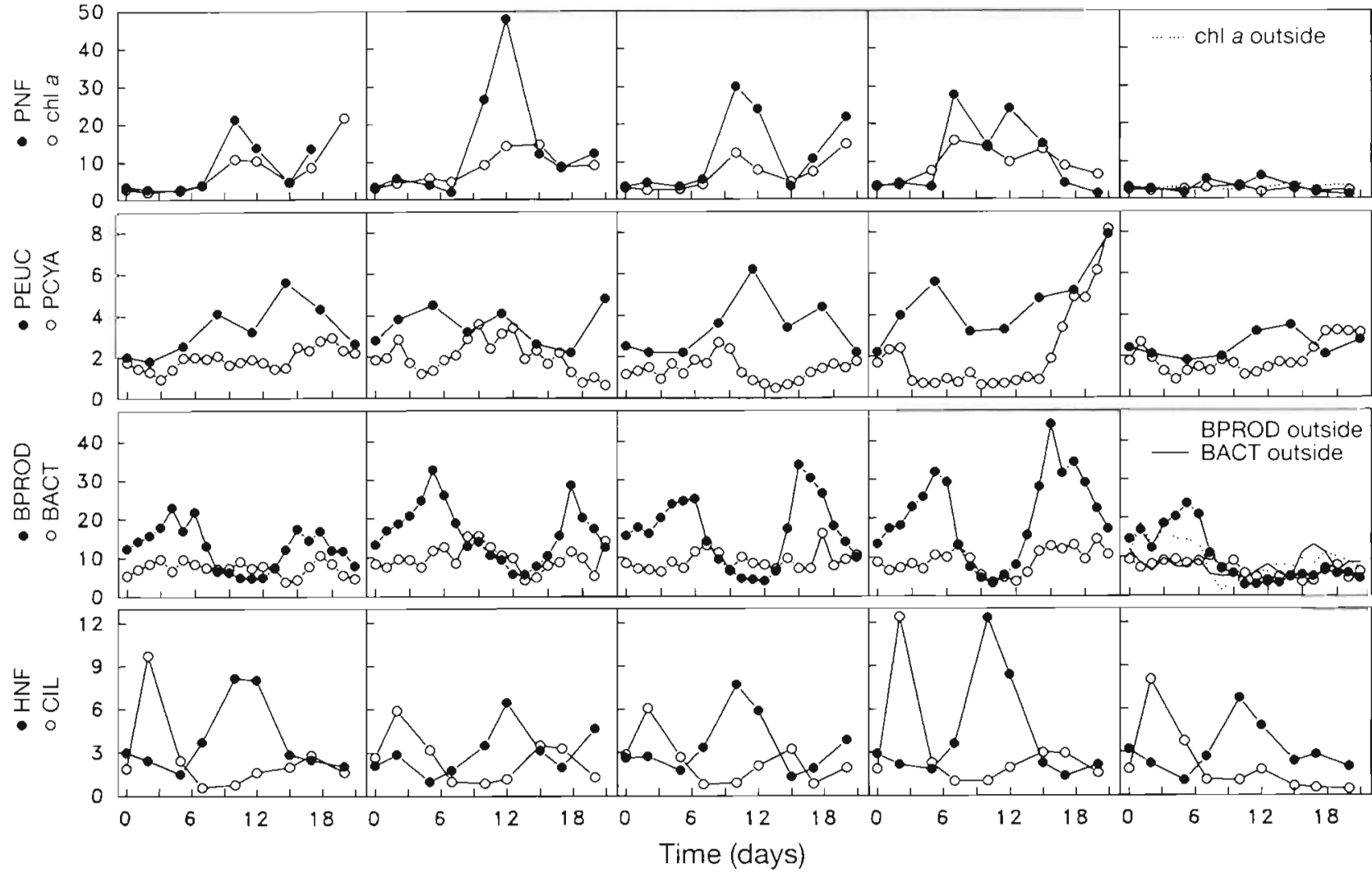

Fig. 3. Succession of $\mathrm{chl} \mathrm{a}\left(\mu \mathrm{g} \mathrm{\textrm {l } ^ { - 1 }}\right.$ ), photosynthetic nanoflagellates (PNF, cells $\times 10^{3} \mathrm{ml}^{-1}$ ), picoplanktonic eukaryotes (PEUC, cells $\times 10^{3} \mathrm{ml}^{-1}$ ), picoplanktonic cyanobacteria (PCYA, cells $\times 10^{5} \mathrm{ml}^{-1}$ ), bacterial production (BPROD, cells $\times 10^{4} \mathrm{ml}^{-1}$ ), bacterial numbers (BACT, cells $\times 10^{4} \mathrm{ml}^{-1}$ ), heterotrophic nanoflagellates (HNF, cells $\times 10^{3} \mathrm{ml}^{-1}$ ), and ciliates (CIL, cells $\times 10^{3} \mathrm{l}^{-1}$ ), in the enclosures during the mesocosm experiment 
observed although concentrations remained at a low level.

The succession of PNF followed that of chl a (Fig. 3; Spearman rank correlation 0.7871, $p<0.01, n=40$ ). Cell numbers of PNF in all enclosures fluctuated between 1.1 and $47.9 \times 10^{3}$ cells $\mathrm{ml}^{-1}$, with the maximum in Enclosure 2 during Period III. Throughout the experiment PNF numbers were low in the control unit.

\section{Photosynthetic picoplankton}

PEUC cell numbers fluctuated between 1.8 and $7.9 \times$ $10^{3}$ cells $\mathrm{ml}^{-1}$ (Fig. 3 ) in all enclosures, and showed a concurrent development with chl $a$ and PNF (Fig. 3 ; Spearman rank correlation $0.5479, \mathrm{p}<0.01, \mathrm{n}=40$, and $0.4301, \mathrm{p}<0.01, \mathrm{n}=40$, respectively). The numbers of PCYA varied from 4.7 to $81.4 \times 10^{4}$ cells $\mathrm{ml}^{-1}$ (Fig. 3 ) The development of PCYA in the control unit was comparable to that in the manipulated enclosures. The PCYA peak in Enclosure 4, at the end of the experiment, was accompanied by a peak in PEUC. There was no significant correlation between PCYA and the other photosynthetic organisms (Spearman rank correlations with chl a, PNF and PEUC were -0.1173 (ns), - -0.1051 (ns), and 0.0026 (ns) respectively; for all variables $\mathrm{n}=40)$.

The average production rate of PCYA, calculated using their growth constant in $<1 \mu \mathrm{m}$ fraction in the enclosures, was $2.3 \times 10^{3}$ cells $\mathrm{ml}^{-1} \mathrm{~h}^{-1}$.

\section{Bacteria}

BPROD oscillated with the same frequency in all manipulated enclosures (Fig, 3), varying between 2.7 and $44.3 \times 10^{4}$ cells $\mathrm{ml}^{-1} \mathrm{~h}^{-1}$. The first peak was observed on Days 4 to 6 , and the second peak on Days 15 to 17 . The height of the peaks was different, being more pronounced in the manipulated enclosures than in the control. Bacterial cell numbers (BACT) followed BPROD with a lag of 1 to $2 \mathrm{~d}$. BACT fluctuated between 3.7 and $16.2 \times 10^{6}$ cells $\mathrm{ml}^{-1}$. BPROD and $\mathrm{BACT}$ in the control unit closely resembled those outside the enclosures (Fig. 3).

\section{Heterotrophic nanoflagellates and ciliates}

During this experiment, Vørs (1992) found 31 to 44 taxa of nano-sized heterotrophic protists (flagellates and amoebae) in the enclosures. The dominant flagellate groups were bodonids, bicosoecids, chrysophytes and ungrouped flagellates ('incertae sedis'). The high- est number of taxa was found in Enclosure 4, where the highest flagellate cell number was also observed. The abundance of HNF in the enclosures ranged from 1.0 to $12.3 \times 10^{3} \mathrm{ml}^{-1}$ (Fig. 3). The same successional pattern of HNF was observed in all enclosures including the control, irrespective of manipulations, with only the height of the peak being different

The periodicity in the coupled oscillations of HNF and BPROD was 4 to $5 \mathrm{~d}$ in all enclosures. In Enclosure 4 where the highest peak of BPROD was detected, the highest peak of HNF was also found (Fig. 3), clearly implying the close interaction between these 2 groups. Coupled oscillations were less apparent between the cell numbers of prey and HNF (HNF and BACT, HNF and PCYA) (Fig. 3). Average cell production of HNF in the enclosures, based on their specific growth rates in $<5 \mu \mathrm{m}$ filtrate, was $1.4 \times 10^{2}$ cells $\mathrm{ml}^{-1} \mathrm{~h}^{-1}$.

The total number of CIL ranged from 0.43 to $12.4 \times$ $10^{4}$ cells $l^{-1}$ (Fig. 3). The maximum value was found in Enclosure 4. The initial peak, which was found in all enclosures including the control, consisted of small Urotrichia, Strobilidium, Strombidium, Mesodinium and Lohnanniella species. During the second, minor peak, large ciliates such as Holophrya, Lohmanniella spiralis, Didinium and Leprotintinnus bottnicus had become more numerous. Nanociliates $(<20 \mu \mathrm{m})$ were present ( 0 to $4.9 \times 10^{3}$ cells $l^{-1}$, mean $8.1 \times 10^{2}$ cells $l^{-1}$ ) in all enclosures. The number of heterotrophic dinoflagellates in the mesocosms was $<1$ ind. $1^{-1}$ throughout the experiment.

Predator-prey-like oscillations between $\mathrm{HNF}$ and CIL, as well as between PNF and CIL, were observed in all enclosures, fluctuating with a lag of ca $1 \mathrm{wk}$ (Fig. 3). The frequencies of the oscillations between BPROD and HNF, HNF and CIL, and PNF and CIL were similar in all enclosures irrespective of the manipulations.

\section{Carbon flow in Enclosure 1}

The carbon budget, constructed for Enclosure 1, was divided into 4 phases according to the manipulation periods (Table 1). The microbial succession in the enclosure was consistent with the phases: during Period I, BPROD and CIL abundance peaked whereas HNF abundance was at a minimum (Fig, 3, Enclosure 1). The converse was true for Period II. Period III exhibited a declining HNF community but an increase in BPROD and CIL abundance, and Period IV was characterized by a small and declining HNF community and declining BPROD rate, but also by a second CIL peak consisting of larger species. During all periods, the PCYA community showed increased growth.

Addition of inorganic nutrients enhanced phytoplankton production in the enclosure. Apparent net 
production increased from 195 to $1175 \mu \mathrm{g} \mathrm{C} \mathrm{l}^{-1}$ per$\operatorname{iod}^{-1}$ during the experiment.

Autotrophic picoplanktonic biomass doubled during the experiment (Fig. 4). Most of the increase was due to PCYA, which formed ca 75 to $85 \%$ of the autotrophic picoplankton biomass. During the first 2 manipulation periods PCYA accounted for 11 and $18 \%$ of the total primary production, but only 0.3 and $2 \%$ during Periods III and IV (Fig. 4). The integrated PCYA production was nearly 3 times its biomass during Periods I and II (Fig. 4), but after the decline in water temperature (Fig. 1) production dropped to between 25 and $100 \%$ of the biomass (Fig. 4). PCYA loss rates balanced production during all periods. Grazing by HNF contributed to more than one-third of their loss, and in fact during the HNF maximum they were responsible for all of the PCYA loss (Fig. 4). During Periods II and III, HNF grazing on PCYA, estimated by the fractionation technique, exceeded the total loss of PCYA by 10 to $15 \mu \mathrm{g} \mathrm{Cl}^{-1}$ period $^{-1}$ (Fig. 4).

Bacteria dominated the picoplankton (95 to $115 \mu \mathrm{g} \mathrm{C}^{-1}$ ) in the enclosure, constituting 80 to $90 \%$ of the total picoplankton biomass (Fig. 4). During Period I, bacterial production was 1.5 times greater than primary production, but had declined to 45,15 and $21 \%$ of the primary production during Periods II, III and IV, respectively. Integrated bacterial production (140 to $295 \mathrm{\mu g} \mathrm{C} \mathrm{l}^{-1}$ period $^{-1}$ ) was 1.5 to 2.6 times the standing stock (Fig. 4). Unlike PCYA production, bacterial production was not affected by changes in water temperature. Bacterial carbon production remained fairly constant throughout the experiment, whereas PCYA production decreased to one-fifth after the temperature drop (see Fig. 1).

Bacterial production and loss rates were balanced throughout the experiment (Fig. 4), only during Period I was the loss rate exceeded by production. The fate of bacterial carbon varied considerably during the experiment (Fig. 4). Grazing by HNF was the most significant pathway for bacterial carbon, accounting for 32 to $57 \%$ of bacterial loss during Periods I, III and IV. Flagellate grazing was most intensive during their exponential growth phase in Period II (Fig. 4), when grazing by HNF alone slightly exceeded the calculated total bacterial loss. The high flagellate clearance rate of Period IV was probably due to larger flagellate size and the adaptation of the HNF community to the lower water temperatures. Grazing by CIL accounted for 0 to $39 \%$ of the bacterial loss. During the concomitant decline in the HNF community and increase in the CIL community (Period III, Fig. 3), bac-
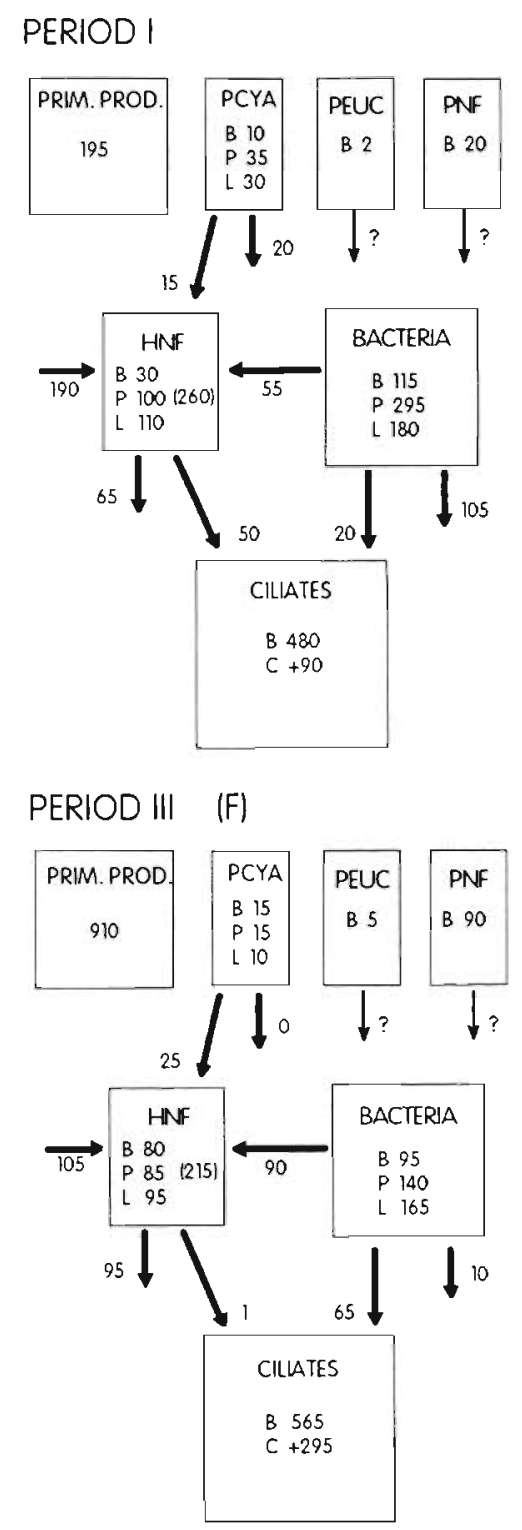

PERIOD IV $(\mathrm{P}+\mathrm{N}+\mathrm{F})$

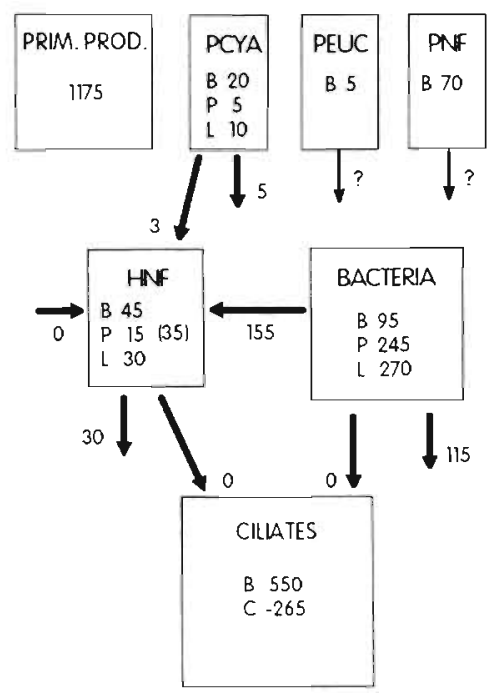

Fig. 4. Carbon flow diagram from picoplankton to ciliates in Enclosure 1, pre-

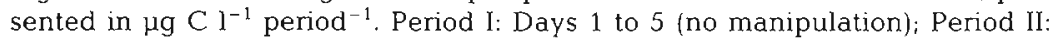
Days 6 to $10(\mathrm{P}+\mathrm{N})$, Period III: Days 11 to 15 (stickleback fry); Period IV: Days 16 to 20 (P+N+fry). B: biomass; P: gross production; L: total loss; $\mathrm{C}$ : net change of ciliate biomass. The arrows indicate the carbon flux from one organism pool to another. The arrow to the left of the HNF pool represents an additional carbon source needed to fulfill the HNF demand (given in parentheses) 
terial grazing by ciliates increased to $70 \%$ of HNF grazing (Fig. 4). Large ciliates probably did not graze on bacteria, since during the second peak (Period IV), which consisted of larger species, carbon flow from bacteria to ciliates was negligible (Fig. 4).

Mixotrophic algae of the genera Pseudopedinella, Pedinella, Chrysochromulina, Pavlova and Prymnesium were present in Enclosure 1. Their numbers were less than $10^{2}$ cells $\mathrm{ml}^{-1}$, except for a peak of pedinellids on Days 8 to 15 with a maximum on Day $11(3.7 \times$ $10^{3}$ cells $\mathrm{ml}^{-1}$ of Pseudopedinella sp., $1.2 \times 10^{3}$ cells $\mathrm{ml}^{-1}$ of Pedinella sp.). The pedinellid maximum occurred at the time of the third grazing experiment (see Kuuppo-Leinikki 1990).

Other loss processes, e.g. sedimentation, autolysis, lysis induced by bacteriophages, and grazing by mesozooplankton, accounted for 0 to $60 \%$ of total bacterial loss in Enclosure 1 (Fig. 4). The importance of other loss processes was highest during Periods I and IV, when the size of the HNF assemblage was at a minimum.

The biomass of PNF (20 to $90 \mu \mathrm{g} \mathrm{C} \mathrm{l}^{-1}$ period $^{-1}$ ) was 1.7 to 6.5 times higher than the biomass of autotrophic picoplankton (Fig. 4).

The HNF biomass ( 30 to $80 \mu \mathrm{g} \mathrm{Cl}^{-1}$ ) was of the same order of magnitude as PNF biomass (Fig. 4). Their biomass was lowest during Period I and highest during Period III. Production exceeded the standing stock

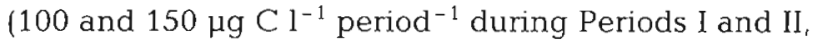
respectively) when water temperature was ca $20^{\circ} \mathrm{C}$, but rates decreased with the temperature drop. During Period IV, HNF production was only $33 \%$ of the biomass. During their exponential growth phase in Period II, (Fig. 4), flagellate production was $75 \%$ of bacterial production.

HNF derived 70 to $295 \mu \mathrm{gC}^{-1}$ period $^{-1}$ from grazing on picoplanktonic prokaryotes (Fig. 4). During Period IV, grazing on BACT exceeded the flagellate carbon need by almost 5-fold (Fig. 4). Carbon flow from BACT to HNF exceeded the total bacterial loss by $9 \%$ and PCYA loss by $25 \%$ during Period II (Fig. 4). The proportion of PCYA in the carbon flow from prokaryotes to HNF was between 2 and $21 \%$, being highest during the growth of the HNF community, and declining together with the decline of PCYA production.

The HNF loss rates varied from 30 to $135 \mu \mathrm{g} \mathrm{C}^{-1}$ period $^{-1}$, slightly exceeding production rates (except during Period II (Fig. 4), even though loss rates were exceptionally high during this intensive growth period]. Ciliates were responsible for 0 to $4 \%$ of HNF loss; however, during the peak of small ciliates (Period I, Fig. 3), 45\% of HNF loss was due to CIL grazing (Fig. 4). HNF biomass decreased with the decline in production.
The microbial biomass was dominated by ciliates throughout the experiment (Fig. 4). Their net biomass change was +90 and $+295 \mu \mathrm{C} \mathrm{C}^{-1}$ period $^{-1}$ during Periods I and III, but became negative during Periods II and IV (Fig. 4). Grazing on BACT and HNF could meet 22 and $78 \%$ of ciliate net production during the growth periods.

\section{DISCUSSION}

\section{Enclosure dynamics}

At the start of the enclosure experiment, chl a concentration was low, typical for the Tvärminne area during summer, when regenerated production prevails in the pelagial (e.g. Niemi 1975, Lignell 1990). Autotrophic picoplankton numbers were low in comparison to the normally oligotrophic midsummer situation (Kuosa 1991b), whereas bacterial cell numbers and production rates were exceptionally high, resembling the situation during the post-bloom period in spring (Virtanen 1985, Kuparinen 1987, 1988). This unusual circumstance, as well as the existence of freshwater species in both phytoplankton and zooplankton communities, was probably a result of freshwater outflow to the coastal area.

Daily additions of inorganic $N$ and $P$ led, as expected, to an increase in both phytoplankton production and biomass. The timing of the manipulation, specifically in relation to the succession of the community, directed its response to each treatment.

The community of picoplanktonic eukaryotes, especially cyanobacteria, showed a different development from that of the total phytoplankton biomass, in addition the PCYA in the control enclosure had a succession comparable to that in the manipulated enclosures. This was very likely due to the different control mechanism of PEUC and PCYA compared to that of the nano-sized and larger phytoplankton: PCYA were not limited by inorganic nutrients in the mesocosms (Wehr 1989, Kuosa 1991a) or controlled by mesozooplankton (Johnson et al. 1982, Iturriaga \& Mitchell 1986). Rather, their production seemed to be, controlled, at least partly, by water temperature, and their biomass by protozoan grazers (e.g. Iturriaga \& Mitchell 1986, Rassoulzadegan et al. 1988, Kuosa 1991 b). The enormous increase in cell numbers of autotrophic picoplankton in Enclosure 4 during Period IV could have been an indirect effect of changes higher up in the food chain, e.g. increased predation on protozoa in this particular enclosure (e.g. by the rotatorian Synchaeta cecilia, data not shown).

In the northern Baltic Sea, during late summerautumn, bacterial production is limited by organic car- 
bon, and/or inorganic nutrients (Autio et al. 1988, Autio 1990, Kuparinen \& Heinänen 1993). In this study the nutrient manipulations enhanced bacterial production. It is probable that the nutrient additions alone could not stimulate bacterial production in the manipulated enclosures, but that the increased amount of labile organic compounds, released from the increased phytoplankton biomass and the sloppy feeding of herbivorous zooplankton (e.g. Lampert 1978), provided an additional carbon supply for the bacteria, thus enhancing bacterial production concomitantly with the nutrient additions. The HNF community responded immediately to the increased bacterial production rate by an increase in biomass. This, in turn, led to a rapid topdown regulation by the grazers of bacterial production rates in the enclosures, perhaps because larger amounts of dividing bacterial cells could be harvested (Sherr et al. 1992), which led to a decline in bacterial production and kept the bacterial standing stock down to a maximum at ca $10^{7}$ cells $\mathrm{ml}^{-1}$ (Fig. 3). The decline in grazing pressure by HNF allowed the bacterial production rate to increase again. Since total phytoplankton biomass remained high, it is not likely that the concentration of bacterial substrates decreased in the enclosures during the experiment. It is quite conceivable that the bacterial population shifted from bottomup control (organic carbon and nutrient deficiency) to top-down control (grazing) during the succession in the mesocosms.

Oscillations in HNF abundance were coupled most closely with bacterial production; the coupling with bacterial cell numbers was not so obvious. It has been shown that HNF graze bacteria by selecting the larger elongated and dividing cells (Andersson et al. 1986, Gonzales et al. 1990, Kuuppo-Leinikki 1990, Sherr et al. 1992), which probably form the productive part of the bacterial standing stock, the bulk of the bacterial biomass being too small for the grazing protozoans.

Coupled oscillations between bacteria, nanoflagellates and ciliates, which are characteristic of microbial communities both in natural environments (Andersen \& Sørensen 1986, Lucas et al. 1987), as well as under experimental conditions (e.g. Bjørnsen et al. 1988), were detected in all enclosures with a 5 to $7 \mathrm{~d}$ lag, which corresponds to the lag periods reported in the literature (e.g. Andersen \& Sørensen 1986). Short-term changes in nutrient loading or top-predator presence did not distort the coupled oscillations. However, in the control enclosure, bacterial production rate did not form a second maximum, as it did in the manipulated enclosures, thereby dampening the coupled oscillations. It seems probable that, in the enclosures, only the second bacterial production peak was affected by the manipulations.
Although the HNF clearance rates of PCYA equalled those of bacteria (Table 2), coupled oscillations between PCYA and HNF could not be detected in the enclosures. Since PCYA cell numbers were unusually low in the experiment (Kuosa 1991b), it is possible that the PCYA community remained at the grazing threshold due to the protozoa being able to immediately use any increased production.

The coupling between small ciliates and both phototrophic and heterotrophic nanoflagellates indicates that flagellates constituted a food source for planktonic ciliates in the enclosures. Such a close coupling could not, however, be seen in the carbon budget: at most only $43 \%$ of HNF carbon was channelled to CIL, and the ciliates could not sustain their growth on HNF alone. Instead of representing a pure predator-prey relationship, the tight numeric coupling of the bacteria-nanoflagellate-ciliate linkage (e.g. Rassoulzadegan \& Sheldon 1986, Bernard \& Rassoulzadegan 1990, Weisse 1990, Weisse \& Scheffel-Möser 1991) could be a consequence of different controlling and limiting factors acting simultaneously.

The manipulated enclosures deviated from the control unit by having higher cell numbers and a more intensive overall fluctuation of the parameters. Larger phytoplankton were directly limited by inorganic nutrients (bottom-up control) and controlled by herbivores. The effect of manipulations with nutrients at the bottom of the food web or with fish at the top of the food web were dampened before reaching the microbial loop (see Horsted et al. 1988), which, on the whole, seemed to be well buffered against these rapidly fluctuating disturbances and increasing eutrophication, keeping its intrinsic cycles unchanged. Structural changes in the structure within the microbial communities probably altered the flow of carbon through the microbial food web.

\section{Carbon budget}

Picoplanktonic cyanobacterial loss

The addition of inorganic nutrients caused eutrophication of the pelagic community in the enclosures. During Periods I and II, the PCYA contribution to the total primary production was low (11 to $18 \%$ ), resembling the situation during the spring bloom (Kuosa 1990a), and with the increasing primary production the importance of PCYA as primary producers became even more negligible. This was also an indication of the eutrophication of the system. Furthermore, the ratios of PCYA and PEUC were close to those estimated by Kuosa (1991a) during summer in the Tvärminne area. PCYA cell production was more clearly 
suppressed by lower water temperatures than bacterial thymidine incorporation.

In Enclosure 1 loss rates of PCYA paralleled cell production, although exceeding it slightly. HNF were responsible for 30 to $100 \%$ of the PCYA loss, which is in agreement with studies done in both freshwater (e.g. Nagata 1988, Weisse 1988) and marine (Hagström et al. 1988, Caron et al. 1991, Kuosa 1991a) ecosystems. HNF grazed 20 to $37 \%$ of the PCYA community daily at higher water temperatures (Periods I and II), and 2 to $10 \%$ at lower temperatures (Periods III and IV), which is within the range found in the Tvärminne area (Kuosa 1991a).

Caron et al. (1991) reported total daily loss rates of 22 to $54 \%$ of the PCYA biomass in a coastal marine ecosystem. In our study, daily loss varied from 5 to $63 \%$ of this biomass. PCYA comprised 1.4 to $32 \%$ of the total picoplankton consumed by HNF per day, which is similar to the results of Caron et al. (1991). Kuosa (1991b) estimated that during summer, of the picoplankton carbon entering the HNF community, almost $60 \%$ comes from PCYA, and that in autumn the percentage increases to over 70 . In this mesocosm experiment, only 2 to $21 \%$ of the prokaryotic picoplanktonic carbon entering the HNF pool came from PCYA. This difference was a direct consequence of the eutrophied situation in the mesocosms, whereas the estimates of Kuosa (1991b) were from an oligotrophic plankton community in which the cell numbers of picoplanktonic cyanobacteria exceed $10^{6} \mathrm{ml}^{-1}$ and their contribution to primary production exceed $50 \%$ (Kuosa 1990a).

Even if the size fractionation technique tends to underestimate the grazing rates of HNF (KuuppoLeinikki \& Kuosa 1990), our estimates of HNF grazing exceeded the total loss of PCYA during Periods II and III (by 1.3- and 2.3-fold, respectively), and of BACT during Period II. However, these discrepancies did not affect the general outline of the carbon budget.

\section{Bacterial loss}

Bacteria always comprised the major proportion of the picoplankton biomass in the enclosures. The heterotrophic planktonic community shifted to an autotrophic one during Period II, when primary production exceeded bacterial production. During Period I a considerable portion of the bacterial carbon had to be allochthonous.

Even if there was a constant increase in primary production during the experiment, bacterial biomass and production were quite stable. The conversion factor

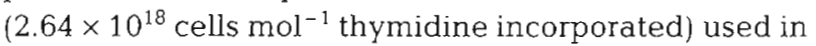
this study was taken from the higher end of the spectrum of estimates from the Baltic Sea (Kuparinen \&
Kuosa 1993). If bacterial production had been calculated using the mean conversion factor given by Kuparinen \& Kuosa (1993) for the Baltic Sea $\left(1.5 \times 10^{18}\right.$ cells $\mathrm{mol}^{-1}$ ), it would have met the needs of protozoan grazing only during Period I, and equalled primary production. Bacterial loss exceeded production most of the time, which was probably an artificial enclosure effect. In this experiment bacterial biomass was mainly exported through HNF grazing. This confirms the role of heterotrophic nanoflagellates as the principal grazers of bacterioplankton in aquatic ecosystems (e.g. Porter et al. 1985, Wikner \& Hagström 1988, Sanders et al. 1989, Bennett et al. 1990, Weisse 1990, Weisse \& Scheffel-Möser 1991).

Short-term changes in bacterial loss routes were most likely a consequence of the coupled oscillations between bacteria and protozoa. When the HNF community was small, other factors accounted for the main bacterial loss (Period I; see Christoffersen et al. 1990). In addition, the drastic decline in water temperature had a direct negative effect on the clearance rates of HNF (Period III, Table 1; Caron et al. 1986, Marrasé et al. 1992).

Even if small ciliates can be effective grazers of bacterioplankton, especially the larger size-classes (Gast 1985, Rivier et al. 1985, Albright et al. 1987. Sherr \& Sherr 1987, Sherr et al. 1989, Epstein \& Shiaris 1992, Simek \& Straskrabová 1992), ciliate bacterivory never exceeded $40 \%$ of the total bacterial loss. During Period IV ciliate grazing on bacteria approached zero. This was most probably a result of the change in the mesocosm ciliate community. Small ciliates, which are known to ingest bacteria, other picoplankton and small flagellates (Rassoulzadegan et al. 1988, Bernard \& Rassoulzadegan 1990), were abundant during the first ciliate peak, whereas larger ciliates favouring larger food (Rassoulzadegan et al. 1988, Kuosa 1990b) formed the later, lower peak at the end of the experiment (Periods III and IV).

Other loss processes explained 43 and $60 \%$ of the bacterial loss during Periods I and IV when HNF were at a minimum. Bacterivory by mixotrophic flagellates (Sanders \& Porter 1988, Sanders et al. 1989, Epstein \& Shiaris 1992) was a potential bacterial loss process during Period III, when mixotrophic pedinellids were at a maximum in Enclosure 1. Potential grazing by mixotrophs could not be distinguished from grazing by true phagotrophs with the fractionation technique used in the grazing experiments. The mixotrophic flagellates (diam. ca $5 \mu \mathrm{m}$ ) were small enough to pass through the $<5 \mu \mathrm{m}$ Nuclepore filter. The grazing impact by mixotrophs was thus included in both the 'HNF grazing' and 'CIL grazing' parts of the calculated carbon budget. However, on the basis of clearance rates (Table 2), the mixatroph contribution was not significant. 
Bacterivorous crustaceans (Christoffersen et al. 1990, Wylie \& Currie 1991, Vagué \& Pace 1992) could have been important during Period III in the enclosure. The cladoceran Daphnia cucullata was present at densities from $3.8 \times 10^{2}$ to $3.8 \times 10^{3}$ cells $\mathrm{m}^{-3}$, and could have been responsible for most of the bacterial loss attributed to 'others' during Period III.

The role of bacteriophages (Proctor \& Fuhrman 1990) can only be speculated on in this study. The first study that included viruses in the carbon budget (Bratbak et al. 1992) emphasized the role of viral lysis as a loss vector for bacterioplankton. They estimated that viral lysis removed $72 \%$ of the bacterial standing stock per day in experimental enclosures. If viruses were responsible for all the bacterial losses in our study, their maximal contribution could have been $60 \%$ of the bacterial standing stock per day.

\section{Heterotrophic nanoflagellates}

Kuosa \& Kivi (1989) estimated that HNF could obtain only half of their carbon requirement from bacteria. In this study, the major carbon source for HNF varied considerably: with a growth efficiency of $40 \%$ (Fenchel 1982a), grazing on prokaryotic prey could have satisfied $27 \%$ of the HNF carbon demand during Period I, and 52 to $78 \%$ of the carbon demand during the flagellate maximum (Fig, 4, values in parentheses). During the exponential growth phase of HNF (Period II), estimated flagellate grazing exceeded the total loss of BACT and PCYA. Even if the total picoplankton loss equalled HNF grazing, grazing on picoplankton would still have satisfied only $70 \%$ of the HNF carbon need. During Period IV, grazing on bacteria exceeded the flagellate carbon need 4.7-fold and was almost twice the HNF biomass, yet there was no increase in HNF biomass at this time. It is possible that the mean cell size of the HNF community in the mesocosm increased considerably during Period IV, but in the calculated carbon budget only one value for cell volume was used during each period. Most likely, the discrepancies between HNF carbon need and supply are due to the HNF growth efficiency used in calculating the budget $(40 \%$; Fenchel 1982a). The gross growth efficiency of the flagellate community estimated in the $<5 \mu \mathrm{m}$ filtrate varied from 105 and $39 \%$ in the first half of the experiment to 0.6 and $3 \%$ in the latter half of the experiment (Kuuppo-Leinikki 1990). Considering these values indicative of the growth efficiency of the total HNF community, the high respiration rate during Period IV would explain the fate of carbon entering the HNF pool from bacterial grazing.
To fulfill their carbon requirements, HNF must have used other sources of nutrition, most likely eukaryotic algae (e.g. Parslow et al. 1986, Suttle et al. 1986, Kuosa 1990 b, Sherr et al. 1991). Since we did not estimate protozoan grazing on PEUC, the carbon flux model is imperfect in this respect. In addition, high molecular organic compounds (Sherr 1988, Marchant \& Scott 1993), or detritus may have served as an extra carbon source for HNF.

\section{HNF-ciliate linkage}

In general, HNF cell production developed in parallel with HNF losses (Fig.4). Despite the close coupling of HNF and CIL communities, grazing by ciliates contributed at most $43 \%$ to the HNF loss in the enclosure, decreasing to zero during the latter half of the experiment. Most of the HNF biomass was probably transported directly to higher trophic levels by crustaceans (Sanders \& Porter 1990), copepod nauplii and rotifers (e.g. reviewed by Stoecker \& Capuzzo 1990). The estimates of carbon flow from HNF to CIL in the budget are conservative during the latter half of the mesocosm experiment, since they are based on $<100 \mu \mathrm{m}$ batch culture incubations, in which larger ciliates were not as numerous as in the enclosure. Bacteria were nearly as important a food source for CIL as were the HNF in terms of carbon. Because BACT and HNF together could satisfy only a small fraction of ciliate carbon needs, other carbon sources, such as picoplanktonic autotrophs and nanophytoplankton (e.g. Rassoulzadegan et al. 1988, Bernard \& Rassoulzadegan 1990 Kuosa 1990b), or mixotrophy (functional chloroplasts; e.g. Stoecker et al. 1987), were probably more important.

Acknowledgements. We thank Naja Vørs and Kjell Gundersen and the PELAG II project, especially Seppo Kaitala, for planning and executing the experiment, Risto Lignell for the primary production data, and Elina Salminen, Pirkko Alanko and Mervi Sjöblom for assistance in the laboratory. The constructive comments by Timo Tamminen, Kai Kivi and the anonymous referees are acknowledged. This study is a contribution of the PELAG project, and it was financed by the Walter and Andrée de Nottbeck Foundation and the Academy of Finland. The English was revised by Maria Ekman-Ekebom (M.Sc.)

\section{LITERATURE CITED}

Albright, L. J., Sherr, E. B., Sherr, B. F., Fallon, R. D. (1987). Grazing of ciliated protozoa on free and particle-attached bacteria. Mar. Ecol. Prog. Ser. 38: 125-129

Andersen, P., Sørensen, H. M. (1986). Population dynamics and trophic coupling in pelagic microorganisms in eutrophic coastal waters. Mar. Ecol. Prog. Ser. 33: 99-109 Andersson, A., Larsson, U., Hagström, §. (1986). Size-selec- 
tive grazing by a microflagellate on pelagic bacteria. Mar. Ecol. Prog. Ser. 33: 51-57

Autio, R. M. (1990). Bacterioplankton in filtered brackish water cultures: some physical and chemical parameters affecting community properties. Arch. Hydrobiol. 117: $437-451$

Autio, R. M. (1992). Temperature regulation of brackish water bacterioplankton. Arch. Hydrobiol. Beih. Ergebn. Limnol. 37: $253-263$

Autio, R. M., Kuparinen, J, Kaitala, S. (1988). Factorial experiments used to analyse nutrient and grazing control of phyto- and bacterioplankton. Arch. Hydrobiol. Beih. Ergebn. Limnol. 31: 253-263

Azam, F., Fenchel, T., Field, J. G., Gray, J. S., Meyer-Reil, L. A., Thingstad, F. (1983). The ecological role of water-column microbes in the sea. Mar. Ecol. Prog. Ser. 10: 257-263

Bennett, S. J., Sanders, R. W., Porter, K. G. (1990). Heterotrophic, autotrophic and mixotrophic nanoflagellates seasonal abundances and bacterivory in a eutrophic lake. Limnol. Oceanogr. 35: 1821-1831

Bernard, C., Rassoulzadegan, F. (1990). Bacteria or microflagellates as a major food source for marine ciliates: possible implications for the microzooplankton. Mar, Ecol. Prog. Ser. 64: 147-155

Bird, D. F., Kalff, J. (1987). Algal phagotrophy; regulating factors and importance relative to photosynthesis in Dinobryon (Chrysophyceae). Limnol. Oceanogr. 32: 277-284

Bjornsen, P. K. (1986). Automatic determination of bacterioplankton biomass by image analysis. Appl. environ. Microbiol. 51: 1199-1204

Bjørnsen, P. K., Riemann, B., Horsted, S. T., Nielsen, T. G., Pock-Stein, J. (1988). Trophic interactions between heterotrophic nanoflagellates and bacterioplankton in manipulated seawater enclosures. Limnol. Oceanogr. 33: $409-420$

Bloem, J., Ellenbroek, F. M., Bär-Gilissen, M.-J. B., Cappenberg, T. E. (1989). Protozoan grazing and bacterial production in stratified Lake Vechten estimated with fluorescently labeled bacteria and by thymidine incorporation. Appl. environ. Microbiol. 55: 1787-1795

Børsheim, K. Y., Bratbak, G. (1987). Cell volume to cell carbon conversion factors for a bacterivorous Monas sp. enriched from seawater. Mar. Ecol. Prog. Ser. 36: 171-175

Bratbak, G., Heldal, M., Thingstad, T. F., Riemann, B., Haslund, O. H. (1992). Incorporation of viruses into the budget of microbial C-transfer. A first approach. Mar. Ecol. Prog. Ser. 83: 273-280

Caron, D. A., Goldman, J. C., Dennett, M. R. (1986). Effect of temperature on growth, respiration and nutrient regeneration by an omnivorous microflagellate. Appl. environ. Microbiol. 52: 1340-1347

Caron, D. A., Lim, E. L., Miceli, G., Waterbury, J. B., Valois, F. W. (1991). Grazing and utilization of chroococcoid cyanobacteria and heterotrophic bacteria by protozoa in laboratory cultures and a coastal plankton community. Mar. Ecol. Prog. Ser. 76: 205-217

Christoffersen, K., Riemann, B., Hansen, L. R., Klysner, A., Sørensen, H. B. (1990). Qualitative importance of the microbial loop and plankton community structure in a eutrophic lake during a bloom of cyanobacteria. Microb. Ecol. 20: 253-272

Ducklow, H. W., Purdie, D. A., Williams, P. LeB., Davies, J. M. (1986). Bacterioplankton: a sink for carbon in a coastal marine plankton community. Science 232: 865-867

Edler, L. (ed.) (1979). Recommendations on methods for marine biological studies in the Baltic Sea. Phytoplankton and chlorophyll. Baltic mar. Biol. Publs 5: 1-38
Epstein, S. S., Shiaris, M. P. (1992). Size-selective grazing of coastal bacterioplankton by natural assemblages of pigmented flagellates, colorless flagellates, and ciliates. Microb. Ecol. 23: 211-225

Fenchel, T. (1982a). Ecology of heterotrophic microflagellates. II. Bioenergetics and growth. Mar. Ecol. Prog. Ser. 8: $225-231$

Fenchel, T. (1982b). Ecology of heterotrophic microflagellates. IV. Quantitative occurrence and importance as bacterial consumers. Mar. Ecol. Prog. Ser. 9: 35-42

Fuhrman, J. A., Azam, F. (1980). Bacterioplankton secondary production estimates for coastal waters of British Columbia, Antarctica, and California. Appl. environ. Microbiol. 39: $1085-1095$

Gast, V. (1985). Bacteria as food for microzooplankton in the Shclei Fjord and Baltic Sea with special reference to ciliates. Mar. Ecol. Prog. Ser. 22: 107-120

Geertz-Hansen, O., Olesen, M., Bjørnsen, P. K., Larsen, J. B. Riemann, B. (1987). Zooplankton consumption of bacteria in a eutrophic lake and in experimental enclosures. Arch. Hydrobiol. 110: 553-563

Gonzales, J. M., Sherr, E. B., Sherr, B. F. (1990). Size-selective grazing on bacteria by natural assemblages of estuarine marine flagellates. Appl. environ. Microbiol. 56: 583-589

Haas, L. W. (1982). Improved epifluorescence microscopy for observing planktonic microorganisms. Annls Inst. océanogr. Paris 58: 261-266

Hagström, A., Azam, F., Andersson, A., Wikner, J., Rassoulzadegan, F. (1988). Microbial loop in an oligotrophic pelagic marine ecosystem: possible roles of cyanobacteria and nanoflagellates in the organic fluxes. Mar. Ecol. Prog. Ser. 49: 171-178

Hobbie, J. E., Daley, R. J., Jasper, S. (1977). Use of Nuclepore filters for counting bacteria by fluorescence microscopy. Appl. environ. Microbiol. 33: 1225-1228

Horsted, S. J., Nielsen, T G., Riemann, B., Pock-Steen, J., Bjornsen, P. K. (1988). Regulation of zooplankton by suspension-feeding bivalves and fish in estuarine enclosures. Mar. Ecol. Prog. Ser, 48: 217-224

Iturriaga, R., Mitchell, B. G. (1986). Chroococcoid cyanobacteria: a significant component in the food web dynamics of the open ocean. Mar. Ecol. Prog. Ser. 28: 291-297

Jeppesen, E., Sørtkjær, O., Søndergaard, M., Erlandsen, M. (1992). Impact of a trophic cascade on heterotrophic bacterioplankton production in two shallow, fish-manipulated lakes. Arch. Hydrobiol. Beih. Ergebn. Limnol. 37: 219-231

Johnson, P. W., Huai-Shu, X., Sieburth, J. McN. (1982). The utilization of chroococcoid cyanobacteria by marine protozooplankters but not by calanoid copepods. Annls Inst. océanogr. Paris 58: 297-308

Kivi, K., Kaitala, S., Kuosa, H., Kuparinen, J., Leskinen, E. Lignell, R., Marcussen, B., Tamminen, T. (1993). Nutrient limitation and grazing control of Baltic plankton community during annual succession. Limnol. Oceanogr. 38 : $893-905$

Kuosa, H. (1988a). Enumeration of autotrophic and heterotrophic flagellates in Baltic Sea samples - a comparison of microscopical methods. Arch. Hydrobiol. Beih. Ergebn. Limnol 31: 301-306

Kuosa, H. (1988b). Occurrence of autotrophic picoplankton in an open sea-inner archipelago gradient in the Gulf of Finland. Ophelia 28: 85-93

Kuosa, H. (1990a). Picoplanktonic cyanobacteria in the northern Baltic Sea: role in the phytoplankton community. In: Barnes, M., Gibson, R. N. (eds.) Proc. 24th Eur. Mar. Biol. Symp. Aberdeen University Press, Aberdeen, p. 11-17

Kuosa, H. (1990b). Protozoan grazing on pico- and nano- 
phytoplankton in the northern Baltic Sea: direct evidence from epifluorescence microscopy. Arch. Hydrobiol. 119 $257-265$

Kuosa, H. (1991a). Microbes in the pelagic carbon cycle picoplanktonic algae and heterotrophic nanoflagellates in the northern Baltic ecosystem. Ph.D. thesis. Walter and Andrée de Nottbeck Foundation Scientific Reports 6 Helsinki

Kuosa, H. (1991b). Picoplanktonic algae in the northern Baltic Sea: seasonal dynamics and flagellate grazing. Mar. Ecol Prog. Ser. 73: 269-276

Kuosa, H., Kivi, K. (1989). Bacteria and heterotrophic flagellates in the pelagic carbon cycle in the northern Baltic Sea. Mar. Ecol. Prog. Ser. 53: 93-100

Kuparinen, J. (1988). Development of bacterioplankton during winter and early spring at the entrance to the Gulf of Finland, Baltic Sea. Verh. int. Verein. Limnol. 23 $1869-1878$

Kuparinen, J., Heinänen, A. (1993). Inorganic nutrient and carbon controlled bacterioplankton growth in the Baltic Sea. Estuar. coast. Shelf Sci. 37: 271-286

Kuparinen, J., Kuosa, H. (1993). Autotrophic and heterotrophic picoplankton in the Baltic Sea. Adv. mar. Biol 29: $73-128$

Kuuppo-Leinikki, P. (1990). Protozoan grazing on planktonic bacteria and its impact on bacterial population. Mar. Ecol. Prog. Ser. 63: 227-238

Kuuppo-Leinikki, P., Kuosa, H. (1990). Estimation of flagellate grazing on bacteria by size fractionation in the northern Baltic Sea. Arch. Hydrobiol. Beih. Ergebn. Limnol. 34: $283-290$

Lampert, W. (1978). Release of dissolved organic carbon by grazing zooplankton. Limnol. Oceanogr. 23: 831-834

Li, W. K. W. (1986). Experimental approaches to field mea surements: methods and interpretation. In: Platt, T., Li, W. K. W. (eds.) Photosynthetic picoplankton. Can. Bull. Fish. Aquat. Sci. 214: 251-286

Lignell, R. (1990). Excretion of organic carbon by phytoplankton: its relation to algal biomass, primary productivity and bacterial secondary production in the Baltic Sea. Mar Ecol. Prog. Ser. 68: 85-99

Lignell, R., Kaitala, S., Kuosa, H. (1992). Factors controlling phyto- and bacterioplankton in late spring on a salinity gradient in the northern Baltic. Mar. Ecol. Prog. Ser. 84: $121-131$

Lignell, R., Lindqvist, K. (1992). Effect of nutrient enrichment and temperature on intracellular partitioning of ${ }^{14} \mathrm{CO}_{2}$ in a summer phytoplankton community in the northern Baltic. Mar. Ecol. Prog. Ser. 86: 273-281

Lucas, M. I., Probyn, T A., Painting, S. J. (1987). An experimental study of microflagellate bacterivory: further evidence for the importance and complexity of microplanktonic interactions. In: Payne, A. I. L.., Gulland, J. A., Brink, K. H. (eds.) The Benguela and comparable ecosystems. S. Afr. J. mar. Sci. 5: 791-808

Marchant, H. J., Scott, F. J. (1993). Uptake of sub-micrometer particles and dissolved organic material by Antarctic choanoflagellates. Mar. Ecol. Prog. Ser. 92: 59-64

Marrasé, C., Lim, E. L., Caron, D. A. (1992). Seasonal and daily changes in bacterivory in a coastal plankton community. Mar. Ecol. Prog. Ser. 82: 281-289

Nagata, T. (1988). The microflagellate-picoplankton food linkage in the water column of Lake Biwa. Limnol Oceanogr. 33: 504-517

Niemi, $\AA$. (1975). Ecology of phytoplankton in the Tvärminne area, SW coast of Finland. II. Primary production and environmental conditions in the archipelago and the sea zone.
Acta bot Fenn 105: 1-73

Pace, M. L., McManus, G. B., Findlay, S. E. G. (1990). Planktonic community structure determines the fate of bacterial production in a temperate lake. Limnol. Oceanogr. 35 $795-808$

Parslow, J. S., Doucette, G. J., Taylor, F. J. R., Harrison, P. J (1986). Feeding by the zooflagellate Pseudobodo sp. on the picoplanktonic prasinomonad Micromonas pusilla Mar. Ecol. Prog. Ser. 29: 237-246

Pomeroy, L. R. (1974). Microbial processes in the sea: diversity in nature and science. In: Hobbie, J. E., Williams, P. LeB (eds.) Heterotrophic activity in the sea. Plenum, New York, p. 1-24

Pomeroy, L. R., Wiebe, W. J. (1988). Energetics of microbial food webs. Hydrobiologia 159: 7-18

Porter, K. G., Sherr, E. B., Sherr, B. F., Pace, M., Sanders, R. W (1985). Protozoa in planktonic food webs. J. Protozool. 32: $409-415$

Proctor, L. M., Fuhrman, J. A. (1990). Viral mortality of marine bacteria and cyanobacteria. Nature 343: 60-62

Rassoulzadegan, F., Laval-Peuto, M., Sheldon, R. W. (1988) Partitioning of the food ration of marine ciliates between pico- and nanoplankton. Hydrobiologia 159: 75-88

Rassoulzadegan, F., Sheldon, R. W. (1986). Predator-prey interactions of nanozooplankton and becteria in an oligotrophic marine environment. Limnol. Oceanogr. 31: 1010-1021

Riemann, B., Sørensen, H. M., Bjørnsen, P. K., Horsted, S. J., Jensen, L. M., Nielsen, T. G., Søndergaard, M. (1990). Carbon budgets of the microbial food web in estuarine enclosures. Mar. Ecol. Prog. Ser. 65: 159-170

Rivier, A., Brownlee, D. C., Sheldon, R. W., Rassoulzadegan, F. (1985). Growth of microzooplankton: a comparative study of bactivorous zooflagellates and ciliates. Mar Microb. Food Webs 1: 51-60

Sanders, R. W., Caron, D. A., Berninger, U.-G. (1992). Relationships between bacteria and heterotrophic nanoplankton in marine and fresh waters: an inter-ecosystem comparison. Mar. Ecol. Prog. Ser. 86: 1-14

Sanders, R. W., Porter, K. G. (1988). Phagotrophic phytoflagellates. In: Marshall, K. C. (ed.) Advances in microbial ecology, Vol. 10. Plenum, New York, p. 167-192

Sanders, R. W., Porter, K. G. (1990). Bacterivorous flagellates as food resources for the freshwater crustacean zooplankter Daphnia ambigua. Limnol. Oceanogr. 35: 188-191

Sanders, R. W., Porter, K. G., Bennett, S. J., DeBiase, A. E. (1989). Seasonal patterns of bacterivory by flagellates, ciliates, rotifers, and cladocerans in a freshwater plankton community. Limnol. Oceanogr. 34: 673-687

Sherr, E. B. (1988). Direct use of high molecular weight polysaccharide by heterotrophic flagellates. Nature 335 348-351

Sherr, E. B., Rassoulzadegan, F., Sherr, B. F. (1989). Bacterivory by pelagic choreotrichous ciliates in coastal waters of the NW Mediterranean Sea. Mar. Ecol. Prog. Ser. 55: 235-240

Sherr, E. B., Sherr, B. F. (1987). High rates of consumption of bacteria by pelagic ciliates. Nature 325: 710-711

Sherr, E. B., Sherr, B. F., McDaniel, J. (1991). Clearance rates of $<6 \mu \mathrm{m}$ fluorescently labeled algae (FLA) by estuarine protozoa: potential grazing impact of flagellates and ciliates. Mar. Ecol. Prog. Ser. 69: 81-92

Sherr, B. F., Sherr, E. B., McDaniel, J. (1992). Effect of protistan grazing on the frequency of dividing cells in bacterioplankton assemblages. Appl. environ. Microbiol. 58: $2381-2385$

Simek, K., Straskrabová, V. (1992). Bacterioplankton production and protozoan bacterivory in a mesotrophic reservoir. 
J. Plankton Res. 14: 773-787

Søndergaard, M., Riemann, B., Jensen, L. M., Jørgensen, N. O. G., Bjørnsen, P. K., Olesen, M., Larsen, J. B., GeertzHansen, O., Hansen, J., Christoffersen K., Jespersen, A.-M., Andersen, F., Bosselmann, S. (1988). Pelagic food web processes in an oligotrophic lake. Hydrobiologia 164: $271-286$

Steemann-Nielsen, E. (1952). The use of radio-active carbon (C14) for measuring organic production in the sea. J. Cons. Perm. int. Explor. Mer 18: 117-140

Stoecker, D. K., Capuzzo, J. MCD. (1990). Predation on protozoa: its importance to zooplankton. Review. J. Plankton Res. 12: 891-908

Stoecker, D. K., Michaels, A. E., Davis, L. H. (1987). Large proportion of marine planktonic ciliates found to contain functional chloroplasts. Nature 326: 790-792

Suttle, C. A., Chan, A. M., Taylor, W. D., Harnison, P. J. (1986). Grazing of planktonic diatoms by microflagellates. J. Plankton Res. 8: 393-398

Vagué, D., Pace, M. L. (1992). Grazing on bacteria by flagellates and cladocerans in lakes of contrasting food-web structure. J. Plankton Res. 14: 307-321

Virtanen, A. (1985). Bacterial numbers, biomass, activity and production at a site in the Tvärminne area of the Gulf of Finland. Aqua Fenn. 15: 143-160

This article was submitted to the editor
Vørs, N. (1992). Heterotrophic amoebae, flagellates and heliozoa from the Tvarminne area, Gulf of Finland, in 1988-1990. Ophelia 36: 1-109

Wehr, J. D. (1989). Experimental tests of nutrient limitation on freshwater picoplankton. Appl. environ. Microbiol. 55 $1605-1611$

Weisse, T (1988). Dynamics of autotrophic picoplankton in Lake Constance. J. Plankton Res. 10: 1179-1188

Weisse, T. (1990). Trophic interactions among heterotrophic microplankton, nanoplankton, and bacteria in Lake Constance. Hydrobiologia 191: 111-122

Weisse, T., Scheffel-Möser, U. (1991). Uncoupling the microbial loop: growth and grazing loss rates of bacteria and heterotrophic nanoflagellates in the North Atlantic. Mar. Ecol. Prog. Ser. 71: 195-205

Wikner, J., Hagström, Å. (1988). Evidence for tightly coupled nanoplanktonic predator-prey link regulating the bacterivores in the marine environment. Mar. Ecol. Prog. Ser. 50: $137-145$

Wright, R. T. (1988). A model for short-term control of the bacterioplankton by substrate and grazing. Hydrobiologia 159:111-117

Wylie, L. J., Currie, D. J. (1991). The relative importance of bacteria and algae as food sources for crustacean zooplankton. Limnol. Oceanogr. 36: 708-728

Manuscript first received: April 26, 1993

Revised version accepted: January 24, 1994 